that if properly prepared this would not take place : but if, as was frequdntly the case, an jodate of potassa existed with the iodide of potassium, the iodate might be decomposed, and this was what had taken place in the case related by $\mathbf{M r}$. Elliott. The same effect was also seen in making up the iodide with ceratum cetacei. If the iodate was present it would be decomposed, and the ointment would be coloured; but if the iodide were pure, no colouring would take place.

Dr. C. J. HARE, in addition to the symptoms enumerated by Dr. Lankester, had seen inflammation of the tonsils produced by taking iodide of potassium. He related a case of chronic rheumatism which yielded at once to the iodide on a first attack; but, although under apparently the same circumstances, on a second attack had not had the slightest effect.

\section{REPORTS OF LUNATIC ASYLUMS.}

Mr. Hill requests us to publish the following correspondence, which appears to him, he observes, " to strike at the root of public management in public asylums, and to aim a blow at the general improvement of such institutions."

"To the Chairman of the Visiting Justices of the Dorset County Pauper Lunatic Asylum.

"Sir,-I am induced to make application to yourself, in your official capacity, to be favoured with the last and the preceding report of the Dorchester Lunatic Asylum, having previously applied to the superintendent for the latter ineffectually. I have the honour to be, \&c.

"Robert Gardiner Hrll, Surgeon. " Lincoln, Jan. 29, 1842."

"Dorchester, Feb. 4, 1812.

" $\mathrm{Sir},-\mathrm{I}$ am requested, in reply to your letter to the chairman of the visitors of this county asylum of the 29 th instant, to inform you that there are no reports printed for general circulation, but only sufficient for the magistrates ; consequently they are not able to comply with your request: the report for the last year is not yet from the press. I am, Sir, your very obedient servant, "John Brown."

(For Dr. Button.)

CASE OF MISS A., IN THE LINCOLN ASYLUM FOR THE INSANE.

\section{To the Editor of The LANCET.}

Sir,-You have admitted, without hesitation, into your columns the long-winded rantings and offensive impertinences of the "Looker-ON ;" you have afforded space for the trumpery claptraps and coarse vulgarity of the "ConverT," but you refuse to insert the words of your ingenious friend $\mathrm{Mr}$. Hill, on the plea that they are anonymously sent, though you have, along with them, a reference to the source from which they are drawn, namely, his own journal, and though it is utterly impossible that one so acute as yourself should not perceive that they are disingenuously withheld by him. A journalist ought to be like a judge. He ought to present the evidence with some show, at least, of impartiality. Above all, he ought to have too great a respect for his own position, to suppress facts in homage to popular feeling. Nobody, Sir, who has seen my letter and your notice of it believes that you withhold it from any other cause than a thick-and-thin advocacy of the popular side of the question. The trick which Mr. Hill is practising upon the public is at once shallow and artful; he well knows how easily he may be exposed, but then he speculates upon the protection he has so often received of your editorial ægis. It seems his confidence is not misplaced.

If you, Sir, are contented to be the means through which Mr. Hill is to foist upon the public a story which his own handwriting contradicts, even so let it be. You may keep back the truth for a time, but you cannot destroy it. In no case will I give up my name. Mr. Hill is too good a tactician, as his whole correspondence shows, to give a straightforward answer to a straightforward charge, either openly or anonymously preferred. My name cannot, as you well know, add to the authenticity of the extract which I sent you from his journal, and I do not choose to run the risk of being set up as a butt for the abuse and cant of your anonymous phalanx, with the strong probability of seeing any defence I might make refused as too long or too short for admission, or unimportant to the public, or irrelevant to the main question. The pages, Sir, of your Journal, show that I should not be the first whom you have permitted to be both anonymousiy and irrelevantly attacked, and after some encouragement, and a few honied phrases, abandoned to their fate, by refusing their communications at the precise moment when it was most important to them that you should insert them. On the whole, it gives me some satisfaction to find that the pseudo-philanthropy which you advocate so ably, is put to such straits; for though it is the means by which two very obscure and very ordinary persons of my acquaintance have contrived to thrust themselves into notice, I am every day more and more persuaded that it is founded neither on experience nor humanity, but upon the exertions of three or four bullies, and a well-appointed force of clacqueurs. Sir, I am,

Philadelphus.

** In order to convince the writer that his imputations against our motives for with- 
holding his anonymous and unauthenticated letter from publication are unjust, we here insert the communication from him to which reference was made in our "Notices to Correspondents :"-

\section{To the Elitor of THE LANCET.}

\section{January 21, 1842.}

Sir,-If your note, appended to Mr. Hill's communication, be intended to give him the advantage of a covered retreat, I am wasting my time ; if, however, you wish the public to see fair play, you will withdraw your editorial agis, and let him take his chance. Mr. Hill's simple record of facts is not quite so artless a production as you seem to imagine. Mr. Hill contrasts, by means of extracts from the journals, the violence aud unmanageableness of Miss A. under restraint and under seclusion, in April and August, 1840, with her docility under a nonrestraint management, in December, 1841, at least a year and a half afterwards; and he ascribes the change which time has effected in the case to non-restraint. Mr. Hill takes good care to avoid telling you that only three months before April, 1840 (the time when Miss A. appears to have been so violent under restraint), he made a record, in his own handwriting, which tells of excessive violence under the non-restraint system, and under his own care, superintendence, and management-violence which ended in the mutilation of another patient.

\section{From the Surgeon's Journal.}

“Jan. 5. Miss A. has been unruly, and has broken the water-closet door.

" 8. Miss A. is unruly ; assaulted M. S., who is unimproved.

" 21. Miss A. is refractory. I have given the house-medicine.

" 25. Miss A. broke three panes of glass last night.

“26. Miss A. has been violent.

"30. Miss A. having broken three panes of glass in her way to her sleeping apartment, $I$ have ordered her in future to sleep in an apartment adjoining the gallery.

“Feb. 1. M. S. has a black eye: nurse says Miss A. struck her yesterday morning.

"2. M. S. is very weak, scarcely able to stand by herself; I have desired nurse to put her to bed: the ear is not so much swelled.

\section{"R. G. Hill."}

Now, why did Mr. Hill not make use of these his own records of Miss A.'s case under his own non-restraint system, and

* The note intimated that all replies, containing allegations of fact, contradicting the statements of Mr. Hill, must be authenticated to the editor by a name and address.ED, L. under his own management of it, for the purpose of comparison with the state of the same case three months afterwards? And why did he make use of the records he has made use of in preference? It is in your power, Mr. Editor, to enlighten the public, or to keep them in darkness upon this subject; but, for my own part, I cannot very well see how you can avoid or object to asking him the question. Perhaps, also, he may, if you require it, favour you with a statement of the nature of the injury done by Miss $A$. to M.S.'s ear, and of the appearance of that ear at this present moment. I do not wish to intrude too much upon your pages, else I might put some questions to your elegant, liberal, and zealous correspondent, the "Convert," who, if he was sincere in his former opinions, ought to give others who think as he thought credit for sincerity also. Yours,

Philadelphus.

\section{MEDICAL REGULATIONS}

OF THE

\section{POOR LAW COMMISSIONERS.}

\section{To the Editor of The Lancer.}

SIR, - As the contents of a letter I have this day received from the President of the Royal College of Surgeons will be interesting to many of the readers of The Lanoet, I have inclosed a copy of it, and shall feel obliged if you will insert it in your next Publication. I am, Sir, your obedient servant,

Clapton, Feb. 1, 1842.

\section{Tilomas Hovell.}

\section{" To T. Hovell, Esq., Clapton.}

“4, Berkeley-street, Feb. 1, 1842.

"My dear Sir,-I am glad to have it in $\mathrm{my}$ power to inform you that I have again conferred with the poor-law commissioners on the subject of the various grievances of which the surgeons employed under the poor-law complain, and they have been pleased to make such alterations in their regulations about to be issued as will redress nearly all of them; and $I$ have a confident hope that in the course of a reasonable time the whole will be removed.

"From the various communications I have had at different times with the poor-law commissioners, and particularly with $\mathrm{Mr}$. G. C. Lewis, I am convinced that the members of the medical profession have firm friends in them, and I rely as much on their friendly feelings as on the justice of the claims which may be placed before them.

"A careful inquiry has satisfied me that the total sum paid by the different boards of guardians to all the practitioners in England and Wales in charge of the poor is not half what it ought to be, according to any of 